\title{
The role of Amazonian anthropogenic soils in shifting cultivation: learning from farmers' rationales
}

\author{
$\underline{\text { André B. Junqueira }}^{1,2,3}$, Conny J. M. Almekinders ${ }^{2}$, Tjeerd-Jan Stomph $^{1}$, Charles R. Clement ${ }^{3}$ and Paul C. Struik $^{1}$
}

\begin{abstract}
We evaluated farmers' rationales to understand their decision making in relation to the use of fertile anthropogenic soils, i.e., Amazonian dark earths (ADE), and for dealing with changes in shifting cultivation in Central Amazonia. We analyzed qualitative information from 196 interviews with farmers in 21 riverine villages along the Madeira River. In order to decide about crop management options to attain their livelihood objectives, farmers rely on an integrated and dynamic understanding of their biophysical and social environment. Farmers associate fallow development with higher crop yields and lower weed pressure, but ADE is always associated with high yields and high weeding requirements. Amazonian dark earths are also seen as an opportunity to grow different crops and/or grow crops in more intensified management systems. However, farmers often maintain simultaneously intensive swiddens on ADE and extensive swiddens on nonanthropogenic soils. Farmers acknowledge numerous changes in their socioeconomic environment that affect their shifting cultivation systems, particularly their growing interaction with market economies and the incorporation of modern agricultural practices. Farmers considered that shifting cultivation systems on ADE tend to be more prone to changes leading to intensification, and we identified cases, e.g., swiddens used for watermelon cultivation, in which market demand led to overintensification and resulted in ADE degradation. This shows that increasing intensification can be a potential threat to ADE and can undermine the importance of these soils for agricultural production, for the conservation of agrobiodiversity, and for local livelihoods. Given that farmers have an integrated knowledge of their context and respond to socioeconomic and agro-ecological changes in their environment, we argue that understanding farmers' knowledge and rationales is crucial to identify sustainable pathways for the future of ADE and of smallholder agriculture in Amazonia.
\end{abstract}

Key Words: Amazonia; Amazonian dark earths; decision making; intensification; slash and burn; swidden cultivation; terra preta

\section{INTRODUCTION}

Shifting cultivation is one of the most important forms of agriculture in the tropics, forming the subsistence base for many communities, while contributing substantially to local and regional markets (Coomes et al. 2000, Padoch and Pinedo-Vasquez 2010). Demographic (e.g., population growth, migration), economic (e.g., market integration), and political (e.g., policies encouraging the production of cash crops or forest conservation) pressures are driving major changes in shifting cultivation systems, resulting in agricultural intensification or other types of land use (van Vliet et al. 2012). The impacts of these changes on local livelihoods are both positive, e.g., increases in income, access to health care and education, and negative, e.g., loss of cultural identity, exacerbated inequities, and increased emigration (van Vliet et al. 2012).

Shifting cultivation systems are widespread in Amazonia and are the most common form of upland agriculture, practiced by the majority of the rural population and producing most of the food consumed in the region (Serrão et al. 1996, Coomes et al. 2000). Despite extensive land-use changes in Amazonia in the last decades (Laurance et al. 2001, Mittermeier et al. 2003, Soares-Filho et al. 2006), the number of studies that specifically relate these changes to shifting cultivation practices is limited (van Vliet et al. 2012, 2013).

The most important drivers of land-use and livelihood changes in Amazonia are the development of markets, infrastructure, and social, environmental, and land tenure policies (van Vliet et al. 2013). Trends in shifting cultivation systems in Amazonia are, however, hard to generalize. In some areas these systems are in decline caused by labor shortages (Steward 2007), out-migration or increased off-farm income (Parry et al. 2010); in other areas they are stable or increasing, for example, caused by growing population pressure (van Vliet et al. 2013). This variation reflects the cultural, socioeconomic, and environmental diversity of Amazonia and also the complexity of diversification strategies developed by smallholders across the region (Steward 2007, Padoch et al. 2008, van Vliet et al. 2013).

Farmers acknowledge and deal with changes in their agroecological and socioeconomic environment in many different ways. Changing economic conditions mediated by institutional factors can trigger individual and collective responses that result in land-use changes (Lambin et al. 2001). Instead of being only pushed and pulled by external driving forces, however, farmers are active and informed actors in their responses to changes in their environment (Cramb et al. 2009, Feintrenie et al. 2010). Farmers' decisions to continue with shifting cultivation or to change their land-use practices involve their perceptions and attitudes toward risks and can be based as much on economic rationales as on tradition or other reasons (Nielsen et al. 2006).

Different environmental and socioeconomic contexts provide different opportunities and constraints for agricultural diversification and livelihood strategies (Almekinders et al. 1995). Households are constantly confronted with choices that must be weighed to guarantee their production and reproduction (McCusker and Carr 2006). Local and national markets and policies can create opportunities or constraints for certain types of land use (Lambin et al. 2001), but farmers' opportunities also

${ }^{1}$ Centre for Crop Systems Analysis, Wageningen University, ${ }^{2}$ Knowledge, Technology and Innovation Group, Wageningen University, ${ }^{3}$ Coordenação de Tecnologia e Inovação, Instituto Nacional de Pesquisas da Amazônia 
depend on the type and heterogeneity of the landscapes that they can manage. Environments with poor soils, steep slopes, and intense rainfall, for example, are not amenable to certain types of agricultural intensification (Cramb 2005). Especially in societies that rely heavily on agriculture, soil heterogeneity can play an important role because different soils may favor or restrict certain crop assemblages or management strategies, offer different opportunities for resource use and management, and also coevolve with knowledge, practices, and with the crops themselves. In Central Amazonia, anthropogenic soils add considerable heterogeneity to the soil landscape and play an important role in local cultivation systems.

Amazonian dark earths (ADE or "terra preta") are patches of highly fertile anthropogenic soils formed at pre-Columbian habitation sites (Neves et al. 2003). Today many of them are inhabited and/or used as part of shifting cultivation systems, representing opportunities for diversification of agricultural production and livelihood strategies. Amazonian dark earths contrast strongly with adjacent nonanthropogenic soils, which in most of Amazonia are infertile and acidic (Chauvel et al. 1987). The differences in soils are reflected in differences in weed community composition and growth (Major et al. 2003, 2005), in the assemblage of cultivated crops and landraces (Fraser et al. 2011a, b, 2012, Kawa et al. 2011), and in the composition and usefulness of fallow vegetation (Junqueira et al. 2010, 2011). Shifting cultivation systems on ADE are very heterogeneous and often more intensified when compared to other upland soils, with shorter fallow periods (German 2003a, Fraser et al. 2012) and/or focused on nutrient-demanding crops (Kawa et al. 2011). Production systems on ADE are considered a model for sustainable agriculture (Glaser et al. 2001, Glaser 2007, Kawa and Oyuela-Caycedo 2008) based mainly on the idea that fertile soils can be farmed more intensively and, therefore, would reduce the need to open new areas for cultivation. However, there has been little research to understand how the current use of ADE and the drivers and consequences of their intensive cultivation are explained by farmers' knowledge and reasoning. This would allow us to understand farmers' decision making under changing conditions, to identify relevant research and effective strategies to support sustainable shifting cultivation systems, and to improve farmers' livelihoods.

We explore farmers' practices and rationales related to shifting cultivation on ADE and adjacent nonanthropogenic soils. We interviewed 196 farmers and focused on (1) the way they use ADE as part of their shifting cultivation system; (2) how they deal with demographic, socioeconomic, and political changes in their context; and (3) how these changes affect the way they consider and use ADE. We take as a point of departure farmers' knowledge and rationales in the shifts themselves, that is, when existing swiddens are abandoned, i.e., are left under a more or less intensively managed fallow vegetation, and new ones are established. These decisions to abandon one and open another swidden are strategic moments in the management of shifting cultivation systems and have immediate as well as long-term implications, affecting fallow periods, productivity, and farmers' livelihood opportunities. By focusing on ADE, it is possible to evaluate the role that soil heterogeneity has in farmers' decision making and in the diversification of cultivation systems and livelihood strategies. This information is important for identifying potential opportunities and threats to shifting cultivation systems in Amazonia, as well as for developing more efficient interventions aiming to support local livelihoods and thus to increase the sustainability of cultivation systems on ADE and on adjacent soils in a changing environment.

\section{METHODS}

\section{Research design and interviews}

This research was carried out between 2006 and 2013 along the middle and lower Madeira River, Central Amazonia, Brazil (Fig. 1). The data collection was divided in two phases. In the first phase, we aimed to obtain an overview of the different agricultural uses of ADE and adjacent soils and of farmers' perceptions about the changes taking place in their socioeconomic context (Table 1). For that, we travelled along a $\sim 400 \mathrm{~km}$ stretch of the Madeira River in the municipalities of Manicoré, Novo Aripuanã, and Borba (Fig. 1), visiting villages located on top or close to ADE patches and situated in different geographical and socioeconomic contexts (e.g., at different distances from cities, with different market orientation, etc.). In each village, we collected information on the use of ADE and on what farmers could tell us about changes taking place in their context through unstructured interviews with farmers we found present, without any specific selection criteria. In this first phase, we visited 21 villages and had 196 encounters in which we interviewed 1 or more farmers (an encounter could be with more than 1 farmer or members of a household).

Fig. 1. Location of study sites along the middle and lower Madeira River, Central Amazonia, Brazil. White dots show visited patches of Amazonian dark earths (ADE), and triangles show the seven villages where in-depth research was conducted. The map is composed of a mosaic of LANDSAT images from 2009-2010, obtained from the U.S. Geological Survey.

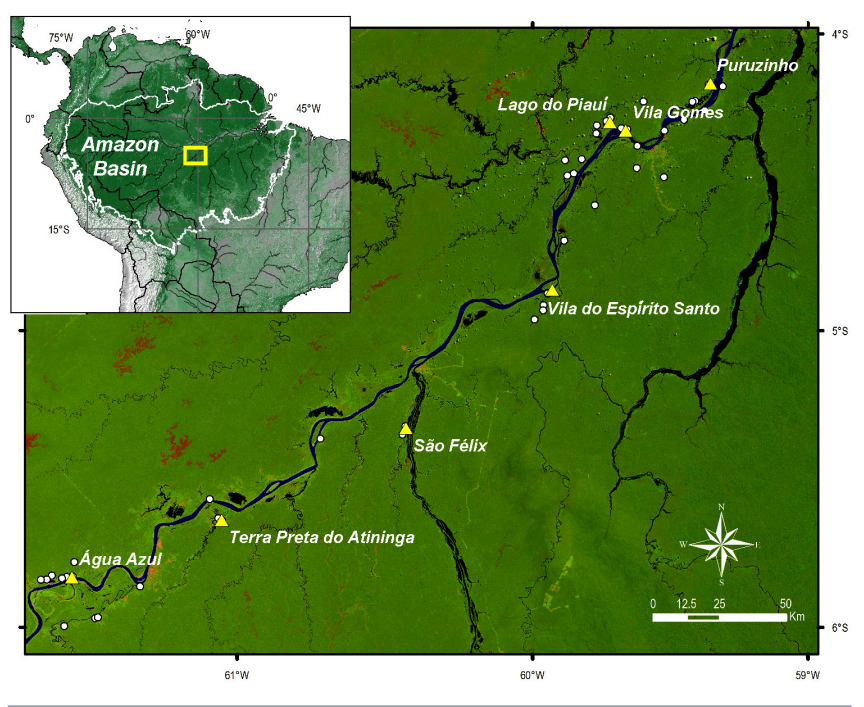

For the second phase of the data collection, we selected a subsample of seven villages. We chose villages in which we had observed (during the first phase) the largest variation in soil properties and that were relatively well spaced along the river (Fig. 1). We spent 12 to 15 days in each village, conducting participant 
Table 1. Summary of the sampling design, the data collection methods used and the type of information obtained in the two phases of the research. ADE = Amazonian dark earths.

\begin{tabular}{lcclll}
\hline \hline $\begin{array}{l}\text { Research } \\
\text { phase }\end{array}$ & $\begin{array}{c}\text { No. of } \\
\text { villages } \\
\text { visited }\end{array}$ & $\begin{array}{c}\text { No. of farmers } \\
\text { interviewed }\end{array}$ & $\begin{array}{l}\text { Time spent in } \\
\text { each village }\end{array}$ & Data collection methods & Type of information obtained \\
\hline Phase 1 & 21 & 196 & $<1$ day & Direct observation & $\begin{array}{l}\text { Overview of the different agricultural uses of } \\
\text { ADE and adjacent soils } \\
\text { Farmers' perceptions about changing context }\end{array}$ \\
Phase 2 & 7 & 92 & $12-15$ days & $\begin{array}{l}\text { Unstructured interviews } \\
\text { Participant observation } \\
\text { Unstructured interviews } \\
\text { In-depth interviews }\end{array}$ & $\begin{array}{l}\text { Cultivation practices and dynamics } \\
\text { Farmers' perceptions about changing context } \\
\text { Local rationales about the cultivation of } \\
\text { ADE and adjacent soils } \\
\text { Farmers' criteria for abandoning and } \\
\text { opening up swiddens }\end{array}$ \\
\hline
\end{tabular}

observation and in-depth interviews (unstructured and semistructured) with local farmers. Interviews focused on local cultivation and management practices, on farmers' rationales about the cultivation of ADE and adjacent soils, on farmers' criteria for abandoning and opening swiddens, and on farmers' perceptions about changes in their context (Table 1). Within each village, we selected farmers with different levels of access to ADE, including some who did not use ADE at all for cultivation. In total, in the second phase of the research we interviewed 92 farmers (Table 1).

\section{The study area and studied systems}

The Madeira River and the occurrence of Amazonian dark earths ( $A D E)$

The Madeira River is one of the largest tributaries of the Amazon River, located in the southwestern and central part of the Amazon Basin (Fig. 1). Along the river, two major environments can be distinguished by their biotic and abiotic environmental contrasts: the uplands and the floodplains. Floodplains are subjected to the annual flood pulse of the river; this fertile, dynamic, and highly seasonal environment is home to a specific flora and fauna, as well as to specific forms of human occupation and resource management, all of which are strongly shaped by the annual flood pulse (Junk and Piedade 2010). The uplands are more stable environments because they are not subjected to flooding from the major rivers, although there is seasonality determined by rainfall, and they are generally composed of infertile acidic soils.

Amazonian dark earths occur along the whole Madeira River and its tributaries, and archaeological sites with this type of soil transformation are especially frequent along the middle and lower Madeira (WinklerPrins and Aldrich 2010, Fraser et al. 2011b, Moraes and Neves 2012). The ADE sites along the Madeira typically occur in patches varying in size from 2 to 50 ha and are situated on high bluffs on the margins of the rivers. The abundance of ADE along the Madeira River results from a history of longterm and relatively dense human occupation in the past (Moraes and Neves 2012). The region experienced severe depopulation following European conquest, and the population only began to increase again toward the end of the nineteenth century with the rubber boom (Weinstein 1983). Given the strategic position of ADE patches in the landscape, many of these sites were reoccupied during the colonial period and the rubber boom. The contact between colonists and the local indigenous populations had severe demographic and cultural impacts on the latter and gave origin to a mixed-blood population called Caboclos (Adams et al. 2009), who today form the majority of the population along the Madeira River. The Caboclos form a diverse and highly heterogeneous population, whose culture emerged from the fusion between local and imported elements, and who incorporated indigenous knowledge, technologies, and practices of natural resource use and management to different extents (Adams et al. 2009).

\section{Local livelihoods, resource management, and shifting cultivation} systems

Local livelihoods along the Madeira River are strongly reliant on the use and management of natural resources. Although there is growing interaction with cities and increasing use of industrialized products, agriculture focusing on annual and biannual crops, mainly manioc (Manihot esculenta Crantz), agroforestry, the gathering of forest products, hunting, and fishing form the basis of subsistence and commercial activities. Fishing is an activity that is performed on a daily basis, and it contributes the majority of protein to local diets. Hunting is also a very common practice, and although the frequency with which people engage in this activity and their rates of success are much lower than in fishing, it also provides an important source of protein.

The gathering of nontimber forest products (NTFP) plays a very important role in subsistence and also as a commercial activity. Rubber production with Hevea brasiliensis (Willd. ex Adr. Juss.) Mueller Arg., along the Madeira has never returned to the level of importance observed during the rubber boom, but rubber tapping is common and represents an important source of income for some families. The Brazil nut (Bertholletia excelsa Humb. and Bonpl.) is economically the most important NTFP, and recently there have been important subsidies from the government, which are stimulating more people to engage in gathering. Many other NTFPs are gathered and commercialized, but in smaller quantities, including fibres, "cipó ambé" (Phylodendron spp.), "cipó-titica” (Heteropsis spp.), "jacitara” (Desmoncus spp.), palm leaves or "palha branca" (Attalea spp.), medicinal plants, and fruits, e.g., açaí (Euterpe precatoria Mart. and E. oleracea Mart.), "bacaba" (Oenocarpus bacaba Mart. and O. minor Mart.), 
"patauá" (O. bataua Mart.), "uchi" (Endopleura spp.), "piquiá” (Caryocar villosum (Aubl.) Pers.), etc.

Plant cultivation and management are present in several forms across the landscape. In home gardens, management is very intensive and decisions are taken at the individual plant level, resulting in a floristic composition and structure that is almost entirely anthropogenic. Beyond home gardens are swiddens for cultivation of annual crops, generally within a radius of a couple of kilometres from houses (Junqueira et al. 2016). They are very diverse and heterogeneous in their composition of species and landraces, management strategies, area, and many other characteristics, and it is in these environments in which most of the food consumed and commercialized is produced. When abandoned, they form the "capoeira" (fallow), which lasts for 3-15 years before being opened again for cultivation. The swiddens are mainly cultivated with annual or biannual crops, although fruit trees and palms are planted and/or favored in some swiddens, which results in secondary forests with a high abundance of useful plants (Junqueira et al. 2010, 2011). Manioc is, by far, the most cultivated crop; it is the most important component of the local diet and also the most important crop economically and culturally (Fraser 2010a, Fraser et al. 2012, Junqueira et al. 2016). No other crop in the region is the focus of such elaborated knowledge, and such detailed, ingenious, and labor-intensive practices in cultivation and processing.

\section{RESULTS}

\section{Farmers' knowledge and considerations on opening and abandoning swiddens}

\section{Why, when, and where to open swiddens}

Our interviews indicate considerable variation in the number and size of swiddens that farmers open in a year. Normally it varies between 1 and 4, most often 2; size varies between 0.1 and 2 hectares, most often 1 , but nearly all households maintain at least 1 active swidden to fulfil the family's need for manioc flour, the local staple food. Farmers have been making swiddens for manioc in this landscape for generations, and they consider that being self-sufficient in manioc flour is an important part of their identity. It is a behavior that is expected from a member of the community. Apart from its important subsistence and cultural value, farmers also cultivate manioc for sale, mostly as flour, and this is often their most important source of monetary income. "The swidden is the bank of the farmer." (Quotes are English translations from interviews). Although a cultivated swidden provides an opportunity to meet both subsistence and monetary needs, its success requires careful planning from the very beginning, with the decision of opening being crucial. Months ahead of opening, farmers are already thinking of their future swiddens, discussing them with their relatives, and considering why the swidden will be opened, how it will be opened, planted, and maintained, i.e., the labor required, the seeds, and planting materials that will be needed, and where it will be opened. "This one is just for my family to eat." "This swidden is for the house we are going to build." These considerations are interdependent.

Essentially, the decisions to open and abandon swiddens are the outcomes of balancing labor requirements with other demands. Farmers say they open a new swidden when the older one(s) in cultivation become too burdensome to maintain, i.e., require more weeding, and yields are unsatisfactory. For nonanthropogenic upland soils (NAS), this generally starts to occur after the first cropping cycle. Swiddens on NAS are dominated by bitter manioc, and farmers say that the length of the cropping cycle varies from six months to three years, depending on the landraces that are cultivated and the time it takes for harvesting. Most often harvesting starts 9-10 months after planting and lasts from a couple of months to more than a year. The opening of a swidden requires enormous effort because it is mostly manual labor and usually involves cutting dense vegetation. Farmers say that June/ July is the best period for opening a new swidden because of the low rainfall, which permits sufficient drying to allow it to burn well. Also, when opening during this time of year, the planting coincides with the start of the rainy season (September/October), and farmers say this provides better conditions for plant growth. There is, however, considerable variation in opening and planting times, especially for crops other than bitter manioc, e.g., maize, banana, and watermelon.

Many farmers consider that ADE is suitable for the cultivation of almost everything, in which whatever you plant grows owing to the relatively high fertility of these soils. That being said, fertility is a concept that is not present in farmers' vocabularies, nor does it fit well with how soils are understood. According to farmers, crops like watermelon, maize, or beans, which are commonly cultivated on the floodplains, can only be cultivated successfully on uplands when grown on ADE. This association between specific crops and ADE has an important influence on farmers' decisions about where to open their swiddens or on which crops they will focus.

For the decision about where to open their swiddens, farmers rely on their historical knowledge of the landscape, e.g., previous land uses, combined with a current reading of the soil and vegetation to choose a place that suits their needs. This reading is essential, especially because farmers recognize that environments are dynamic and that their properties or suitability for cultivation change over time. Their decision to establish a new swidden, or on how to cultivate and manage it, reflects an integrated knowledge of the soil and vegetation, as affected by their management practices.

Ease of access, proximity, and land tenure also play important roles in the decision about where to open a new swidden. Because most of the transportation of people and products is by foot or canoe, farmers prefer to establish their swiddens as close as possible to their houses or, in the case of bitter manioc, to the place where the manioc is processed into flour (although the processed product of course also needs to be transported). In most villages, the area used and managed by households is comprised of a mosaic of private lands, which can be formalized or not, and state-owned lands. Although population density is very low and land is not scarce in most villages, farmers say that access to land tends to be more regulated closer to habitation sites, in which both formal, e.g., private properties, and informal rules, e.g., the historical occupation of a given area and kinship ties, are more important and can influence the establishment of new swiddens. "Here at the front [at the river margin] everyone has their own piece of land, back there [further inland] we can make our swiddens wherever we want." Farming on private lands might require agreements with the owner, which can involve payment in 
cash or in labor. Because ADE occur in relatively small areas, closer to habitation sites, and allow the cultivation of crops that cannot be cultivated elsewhere, access to these areas tends to be most regulated by both formal and informal land-tenure rules. These situations and their many variations result in unequal access to ADE when compared to NAS, which affects farmers' decisions on opening their swiddens. "I would be interested in using terra preta, but I do not have it in my land."

Understanding soils and anthropogenic origins of Amazonian dark earths ( $A D E$ )

Farmers recognize the variation in soil properties and always associate them with vegetation differences in terms of (1) fallow development, (2) weeding requirements, or (3) crop suitability:

1. "On this type of clay the fallow takes longer to grow."

2. "Terra preta requires more weeding than other types of land."

3. "This soil is loose, it is better for manioc." and "Maize only grows on terra preta."

For the identification of soils, farmers use physical characteristics, especially texture and color. Soil names commonly start with the words "barro" (clay) or "areia" (sand), followed by a descriptor that is generally a color or a word that details or emphasizes a textural aspect of the soil, e.g., "solto" (loose), "fofo" (soft). Soils that do not easily fit into these general categories are described as "misturado" (mixed), and several combinations of these terms are used to describe them, e.g., "barro amarelo misturado com areia" (yellow clay mixed with sand). The term terra preta (black earth) is used in reference to soils that are darker and loose, and therefore does not always correspond to the scientific definition of anthropogenic soils. When they refer to sites that are darkest and/or with ceramic fragments, which generally correspond to the archaeological sites, they usually add a descriptor meaning true, legitimate, or referring to specific characteristics of these soils, e.g., "terra preta com caiaué" meaning black earth with caiaué, a palm species, Elaeis oleifera (Kunth) Cortés.

People who live on ADE patches or who use them for agriculture or agroforestry are constantly in contact with archaeological artifacts, including lithic materials (stone axes, mortars), earthworks (ditches, excavated trails), and ceramic fragments. There is general agreement that these are remains of former indigenous residents, but there is no consensus about the origin of the soil itself. Most farmers see ADE as a natural type of soil with specific properties, favored for habitation by indigenous people, which would explain the occurrence of the material artifacts. "Indians only liked to live where there is terra preta." In this understanding, there is an essential separation between the characteristics of the soil, i.e., the specific properties of ADE, and the evidence of past human activity, i.e., artifacts.

People actively manage soils in many ways albeit in very small areas and recognize that management can modify soil properties. In their explanations and practices for soil enrichment, fire always plays a central role. Most people do not think that the ADE patches, large and relatively abundant in the landscape, were created by humans. "Terra preta was created by nature itself." A minority of farmers, however, think that the soil itself may have resulted from human activity in the past. Their explanations for the formation of $\mathrm{ADE}$ are related to current practices of soil management, especially to the formation of "terra queimada" (burned earth) in small fires in home gardens and "caieiras," sites where charcoal is produced. Interestingly, their reasoning about the creation of ADE resembles the academic understanding of how these soils were formed, incorporating (1) the temporal dimension, (2) the magnitude of the historical human occupation of the landscape, and the practices of resource use and management that might have led to these transformations, i.e., cultivation and fires:

1. "They [the Indians] were doing this for a long time."

2. "There were many people, far more than we are today."

\section{Reading the vegetation}

Apart from the recognition of variation in soil properties per se, farmers obtain a more complete understanding of soils by observing characteristics of the vegetation. In particular, the observations that relate to labor requirements are prominent. Farmers recognize the stage of development of the vegetation as a direct indicator of the amount of the labor required to open the swiddens and to maintain their productivity. Opening an older fallow, described locally with terms such as tall, thick, or old fallow, means cutting more and larger trees, which requires more labor. On the other hand, farmers say that swiddens opened in older fallows tend to have less weed growth and higher productivity. This balance between labor needed to open and maintain swiddens and productivity of the swidden came to the fore in practically every conversation we had with farmers and is summarized in this quote: "Older fallows require less weeding and produce more, but require more work to cut." Ease of access and proximity also play an important role in this balance: "The tall fallows are far, so we do it [open swiddens] in the short ones."

When it comes to ADE, farmers recognize several contrasts with other upland soils. Farmers say that the vegetation grows faster on ADE, which implies higher weeding requirements, but they also mention that fallows on ADE are denser in the understory, have a higher abundance of palms and lianas, and do not grow as tall as fallows on NAS. Fallows on ADE are thought to be hard to walk through, but at the same time they are easier to open because they tend to be softer, i.e., the trees can be cut more easily. As with NAS, farmers use the development of the vegetation on $\mathrm{ADE}$ as an indicator of the quality for cultivation. The fact that older fallows require less weeding and give higher yields is, however, not strongly emphasized when they talk about ADE. Farmers say that ADE always requires a lot of weeding, even if swiddens are opened from old fallows, and that ADE always produces well, even if swiddens are opened from young fallows (Fig. 2). "Terra preta requires a lot of work to weed, but everything that you plant grows well." Letting the fallow grow, therefore, is not so important to recover productivity or to reduce the need for weeding, and they say this is one of the reasons why swiddens on ADE tend to be opened from younger fallows then on NAS. Also, farmers say that old fallows on ADE are harder to find, and therefore they have fewer options when choosing from fallows in different stages of development on ADE than they have with NAS. However, given the overlap between ADE and current 
habitation sites, patches of ADE are often closer and more accessible, which is a factor in farmers' decisions: "This one [terra preta] requires a lot of weeding, but it is close to home."

Fig. 2. Conceptual diagram showing relationships between fallow length and work required to open the swidden, expected crop yields, and weeding requirements for nonanthropogenic (NAS) and anthropogenic soils (Amazonian dark earths, ADE). Farmers associate increased fallow development with increased work to open the swidden and with higher expected crop yields, but with decreased weeding requirements; this association is much weaker on ADE than on NAS because ADE is always associated with good crop yields and with high weeding requirements.

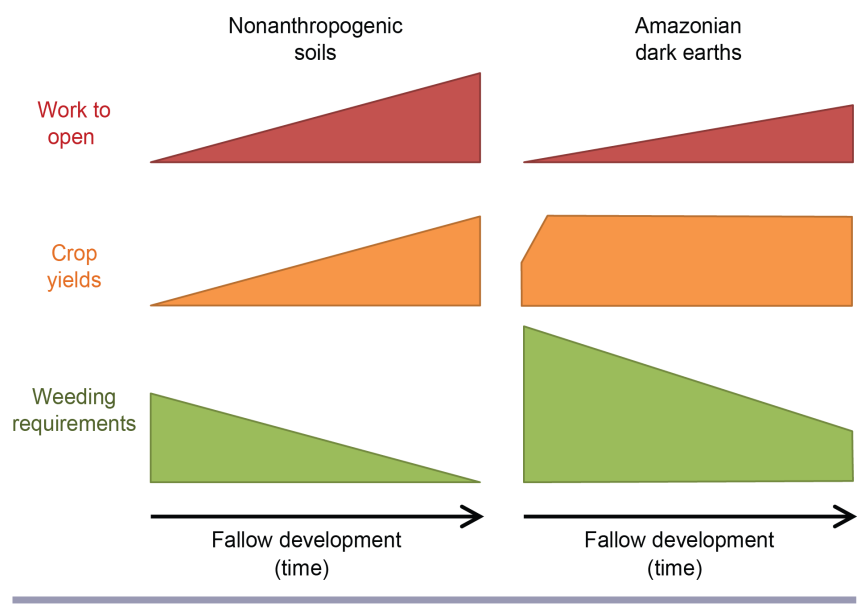

The high weeding requirement for cultivation on ADE is the most common and salient consideration of farmers in their decisions about opening a swidden on these soils. They mention that the number of weedings required before harvesting manioc is almost twice as high on ADE as on NAS. For this reason, they generally open smaller swiddens on ADE than on NAS, and some farmers even avoid cultivating ADE. We recorded some situations in which farmers opened swiddens on ADE but only managed to weed a fraction and had to abandon the remainder.

This reading of the fallow, therefore, enables farmers to project immediate and future labor requirements to obtain a potential yield. This reading recognizes the different soil-vegetation associations of NAS and ADE through time. The diagrams in Figure 2 represent these differences schematically.

\section{The practices of establishing and abandoning swiddens and the role of Amazonian dark earths (ADE)}

\section{The practice of opening new swiddens}

As indicated, opening a new swidden is very labor intensive. Cutting a fallow is normally a male only group activity called "puxirum", a word of Tupi origin that refers to collective activities, organized by the owner of the swidden-to-be. A few days or weeks before his puxirum, the farmer invites a number of fellow farmers to participate. The organizing farmer then owes every person that participates the same amount of work in return, which could be half, one, or a few days' work. The duration of the puxirum and the number of people involved depends on the age of the fallow and the size of the swidden. Thus, older fallows require longer puxiruns because they have larger trees and more of them have hard wood, which makes felling more laborious. Shorter puxiruns involve 3-4 farmers and can last for a few days, but in general a puxirum is thought to last only 1 day, from early morning to the middle of the afternoon, and can involve as many as 20 people. When opening a new swidden, the farmer will have to consider the number of days he will have to work outside his swidden in return for the puxirum, as well as the labor that he and his family will have to invest in weeding, harvesting, and other activities in the swidden. Although puxiruns are still the most common form of organization of collective work, farmers say that puxiruns are gradually being replaced by wage labor.

The owner of the swidden-to-be is the one who decides the exact size and location of the new swidden. He marks the perimeter with stakes, such that the other people who join the puxirum know the limits of the "roçagem," the term for cutting all the vegetation from the understory and the smaller trees with machetes. Larger trees are left to be felled later with axes or chainsaws, in an activity that is called "derrubada," or knock down. The derrubada can be done simultaneously or a few days after the roçagem. After these steps, the vegetation is left to dry for some time before burning. This interval between cutting and burning of the vegetation can last from 10 days to a month, depending on the age of the fallow, (older fallows need longer to dry), but also on the weather: "We need a few days of strong summer before we can burn." Farmers say that the quality of the burn is very important; a bad burn leaves green vegetation behind, which will result in more rapid regrowth and an earlier need for weeding than if the swidden had burned properly. Also, they say that the burned vegetation that is turned into ashes and also some charcoal allows cultivation; therefore they associate better burns with higher yields. Often there is a second burning, the "coivara," in which trees that were not burned properly are piled and burned again. Farmers say that the main reason for making coivaras is to clean their swiddens better, i.e., leave more space for their crops. Farmers also say that each coivara leaves charcoal and ashes accumulated, leading to local modifications in soil properties that are suitable for the cultivation of specific crops, such as banana (Musa $\mathrm{x}$ paradisiaca L.), chili pepper (Capsicum spp.), yam (Dioscorea spp.), etc.

Because farmers state that swiddens on ADE are opened from younger and softer fallows, and are also smaller than NAS swiddens, the labor required for opening swiddens on ADE tends to be lower, less often requiring puxiruns and coivaras. Some swiddens on ADE, however, especially those under more intensive cultivation, may contain an abundance of very aggressive shrubs or treelets, e.g., Acacia sp. and Chomelia anisomeris Müell. Arg., and farmers say that in these situations, their opening requires a lot of effort as well.

\section{The decision to abandon swiddens}

Farmers describe soils as being tired or weak ("terra cansada" or "terra fraca," respectively) when they produce unsatisfactory manioc yields and/or when they are infested with weeds. Farmers report that planting a second time in the same swidden leads to reduced crop yields and higher weeding requirements. Therefore, a typical manioc swidden on NAS is used for one cropping cycle, which may last from one to three years. During the first 8-12 months the swidden is weeded more intensively; then manioc 
harvesting starts, which may last from a few months to more than a year. Once harvesting is finished, farmers usually let the fallow vegetation grow. A swidden is, however, not abandoned completely; the fallows are also managed and contain many useful species, some of which were saved from cutting or burning during opening of the swidden, and others which may have been planted or spontaneously appeared and were favored during the period when the swidden was being managed more intensively. When farmers finish harvesting manioc or other annual/biannual crops, the enriched fallow is subject to lower intensity management.

On ADE, farmers say that they prefer planting crops that produce faster, including specific earlier maturing manioc landraces, so they can reduce the need to weed on these soils as much as possible. On the other hand, successive cropping cycles occur much more often on ADE: "We are always replanting on that area [terra preta], we plant there all the time." "Replanting only works if you do it on terra preta." Swiddens on ADE are more frequently used in multiseason crop rotations (e.g., maize, sweet manioc, and beans) and/or replanting, consequently the swidden can be in cultivation for several years before being abandoned (although the perception that successive plantings on the same plot makes the land tired also applies to ADE. In NAS swiddens, replanting is not a common practice. It is occasionally done in a small part of the original swidden, often while the first crop is still being harvested, or in swiddens that have been opened from old fallows, where "land is stronger" and can sustain two successive cycles.

\section{Changing local context: education, markets, and organizations}

Farmers acknowledge changes in their cultivation systems to different extents and at different time scales. They consider these changes to affect their practices as well as the usefulness of their knowledge and associated cultural values. Changes in access to formal education are frequently mentioned by farmers because these can drive out-migration of children and teenagers and therefore change household labor availability (Fig. 3). People along the Madeira River increasingly have access to formal education because of improvements in the infrastructure provided by the government. Furthermore, having all children at school is a condition for receiving money from the Bolsa Família, the largest Brazilian social program, which provides significant cash income for most of the families in the region. In almost every village there are schools for young children, but teenagers frequently have to move or travel on a daily basis to larger villages or cities in which there is available infrastructure for their continued education. The majority of the families interviewed had at least one son or daughter studying away from the village. Farmers often refer to this out-migration and the intensification of it over the last couple of decades when explaining changes in the management of their swiddens: "Before we used to do big swiddens, now our children have left and we cannot do it anymore."

Farmers also acknowledge their increasing interaction with cities and their growing engagement with the market economy. They report a range of associated changes, such as increasing access to commercial opportunities through better transportation and market organization, e.g., associations, cooperatives: "Today everything planted is sold." They also report changes related to the adoption of modern cultivation techniques, frequently stimulated by state extension organizations (Fig. 3). These include the reduction in the number of landraces cultivated, particularly manioc landraces, and the focus on a few improved, economically profitable ones; the increasing use of fertilizers and pesticides, especially in the cultivation of watermelon; and the increase in mechanization, although limited to weeding machines, chainsaws, and small tractors or motors. As well as providing agronomical recommendations, extension organizations also mediate farmers' access to credit. The presence of these organizations varies strongly between villages, and farmers often complain about their absence or the lack of technical follow-up from extension agents. Still, most of the farmers we interviewed said that they have accessed credit through these organizations. Most often, extension organizations tie this access to credit to the diversification of production activities, thereby stimulating farmers to buy technology packages that usually are associated with more intensive cultivation, e.g., improved landraces, fertilizers, etc.

Fig. 3. Schematic representation of the most important socioeconomic (red) and biophysical (green) factors that farmers take into account in their decision making during shifting cultivation and of the major changes (orange) that they recognize in their socioeconomic environment.

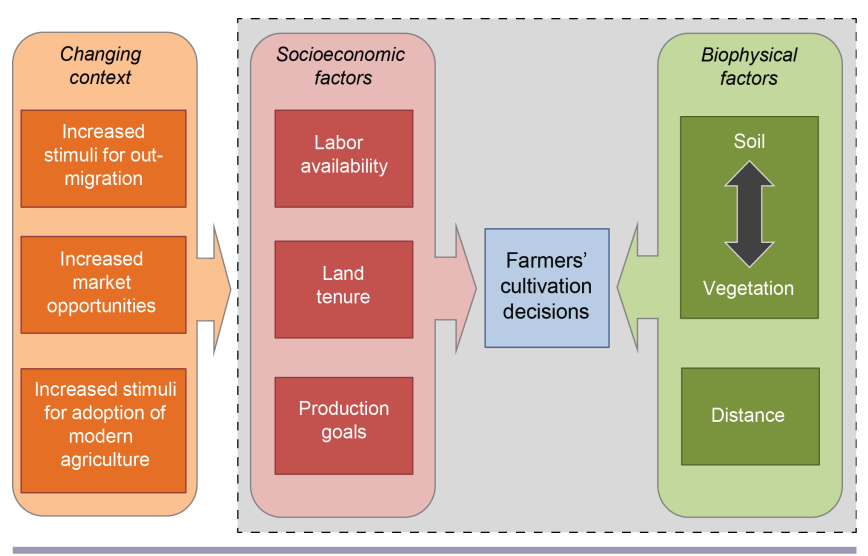

These changes also change perceptions. Farmers, particularly younger ones, consider traditional cultivation techniques oldfashioned, especially cultural and symbolic practices, e.g., synchronizing certain management practices to lunar phases, planting part of the swidden immediately after burning to protect it, etc. Farmers who maintain these practices refer to them with a certain shyness and reticence, as if these traditional practices inherited from the old ones, "dos antigos" have become less important than modern practices: "I don't know the names [of the manioc landraces], it was the old ones who gave these names to the manioc." Despite the fact that manioc occupies a central role in local livelihoods and is the most commonly cultivated crop, farmers point out that young people are less interested in its cultivation, changing their focus to other cash crops or to paid work: "Now nobody here wants to work with manioc anymore." Farmers also consider that labor relationships, in general, are becoming increasingly monetized. The traditional collective puxiruns are gradually being replaced by the payment of daily wages. "Before when we did puxirum we invited a lot of people, but everyone had their [manioc] swiddens. Today not many people make swiddens, so when you invite someone you have to pay [with money]." 
Cultivation systems on ADE are subject to the same trends: reduced labor availability related to out-migration, the increasing engagement with markets, and the adoption of new crops and/or cultivation practices (Fig. 3). The trends do affect ADE differently compared to NAS, however. Farmers say ADE cultivation has always been different than in other soils, tuned to the specific characteristics of this soil. However, they acknowledge that the increasing adoption of cash crops and the intensification of production, through fallow shortening or semipermanent cultivation, have been particularly pronounced on ADE, especially over the last decades. Farmers recall that watermelon, for example, was only grown on floodplains until approximately 30 years ago, when they started planting it on ADE. In some villages, particularly those with better access to markets, watermelon became a major cash crop and led to higher pressure on ADE; farmers started using these areas almost every year, reserving them for watermelon only, and even started renting pieces of ADE land specifically for the cultivation of this crop. This resulted, farmers say, in the weakening of the soil in some places, with declining yields and increasing need for fertilizers and pesticides. These areas now need to be left to fallow for longer periods so that they can recover their strength. Farmers also mention that in certain situations extension organizations stimulate them, via knowledge sharing, but also by mediating access to credit, to cultivate ADE with annual or perennial cash crops that don't grow as well in other upland soils, such as cacao, citrus, or papaya. The intrinsic characteristics of ADE, therefore, favored changes toward intensification and modernization of cultivation systems on these soils and attracted initiatives with similar approaches from extension organizations.

\section{DISCUSSION}

The role of Amazonian dark earths (ADE) in shifting cultivation: diversification and intensification

Our interviews showed that farmers along the Madeira River have an integrated understanding of soils and vegetation dynamics. This knowledge enables them to read the fallow and provides them with indicators of future crop yields and immediate and future labor requirements. They balance these with their crop production opportunities and livelihood needs. This forms the basis of their decision making, particularly that related to opening and abandoning swiddens.

Farmers know that increased fallow development is associated with increased crop yields and decreased labor requirements for weeding in shifting cultivation. Relationships between fallow development, labor, and yields appeared early in the shifting cultivation literature (Nye and Greenland 1960, Boserup 1965, Clarke 1976), although these have not been thoroughly addressed with empirical measurements (Mertz 2002, Nielsen et al. 2006, Mertz et al. 2008). We provide evidence from local rationales that the reading of the fallow is a major source of information upon which farmers rely to make their decisions in shifting cultivation. From farmers' perspectives, however, this association between fallow development and crop yields or labor requirements in shifting cultivation is much weaker on ADE than on NAS, because $\mathrm{ADE}$ is always associated with high labor requirements caused by weed pressure (Fig. 2). The high weed pressure on ADE has also been reported in other studies with a focus on the current cultivation of these soils (German 2003b, Major et al. 2003, 2005, Fraser and Clement 2008, Fraser 2010a, b, Junqueira et al. 2016). This aspect of ADE is very salient in farmers' reasoning and influences many decisions about opening swiddens, their cultivation practices, and the cultivation cycle. Farmers recognize these different relationships in ADE and NAS and use them to decide about opening swiddens, predict future yields, and labor needs.

Despite the high weeding requirements on ADE, farmers value these soils because they offer important opportunities for diversification and intensification, i.e., shorter fallow periods and cropping cycles. The suitability of ADE to cultivate a wider diversity of crops broadens farmers' options for cultivation; the different ways in which farmers deal with these possibilities translates into a great heterogeneity of swiddens on ADE in terms of crop composition, ranging from the staple bitter manioc to multicrop swiddens, to monoculture cash-crop swiddens strictly oriented to the market, e.g., those used for watermelon cultivation (Fraser 2010a, Kawa et al. 2011, Junqueira et al. 2016). Farmers say that the intensification of shifting cultivation is advantageous in situations in which they need to produce quickly, for subsistence or for the market, or when there are significant labor constraints for opening new areas. From a farmer's perspective, opening a swidden on ADE may represent an opportunity to grow different crops, and/or grow crops in different, and often more intensified, management systems, although cultivating on ADE has higher labor costs for weeding. By taking farmers' rationales as a starting point, we showed not only their integrated knowledge of the dynamics of soils and fallows, but also how socioeconomic factors are incorporated into decisions about their production goals and limitations, i.e., different crops, landraces, and labor availability (Fig. 3).

\section{Amazonian dark earths (ADE) and local perceptions and rationales about changing cultivation systems}

Farmers along the Madeira River acknowledge numerous changes in their socioeconomic environment, on different spatial and temporal scales, which affect their shifting cultivation systems (Fig. 3). Among the most important current trends mentioned by farmers is the out-migration of teenagers to towns in pursuit of formal education and their abandonment of agricultural activities, resulting in increasing labor constraints. The growing interaction with market economies and the incorporation of modern agricultural practices were also stressed by farmers in the interviews. They reported that more abundant transportation options and the development of market structures have increased opportunities to sell specific products, and that the role of agriculture is gradually shifting from for subsistence only toward partly subsistence and partly commerce-oriented cultivation. These farmer-perceived changes in their context (Fig. 3) echo patterns described elsewhere in Amazonia (Rudel et al. 2002, Gray et al. 2008, Marquardt et al. 2013, van Vliet et al. 2013). Improved transportation and market opportunities, farmers say, have contributed to the cultivation of new crops, a focus on fewer improved crop landraces, the growing use of fertilizers and pesticides, and (incipient) mechanization. Farmers also mention that access to these new management strategies is facilitated and stimulated by extension organizations through bringing knowledge, but mainly through access to credit. 
In some villages with relatively good geographic and market access, farmers reported intensive cultivation of $\mathrm{ADE}$, in some situations with no or extremely short fallow periods, and a pronounced focus on cash crops (Junqueira et al. 2016). They say that this overintensification has resulted in degraded fallows, i.e., with reduced regeneration and high dominance of aggressive weeds and shrubs, and in the growing dependency on fertilizers or pesticides to maintain satisfactory yields on ADE. Given the intrinsic characteristics of ADE, shifting cultivation systems on these soils tend to be more prone to changes leading to intensification, which according to farmers is being driven mainly by increased market access and interventions from extension organizations. This has implications for understanding the potential role of ADE in how farmers deal with change. On one hand, these soils can increase the opportunities for diversification of cultivation strategies (Junqueira et al. 2016), which is generally beneficial for livelihoods (Ellis 1998). On the other hand, they can attract certain forms of intensification that follow the typical green revolution path (Evenson and Gollin 2003), in which the goal of maximizing productivity occurs at the expense of a greater dependency of markets and external inputs, often with, on a slightly longer term, adverse environmental and social impacts (Godfray et al. 2010, Padoch and Sunderland 2014).

\section{From local rationales to the future of Amazonian dark earths (ADE)}

In the consideration of ADE as a model for sustainability, intensification of production on these soils is assumed (Glaser et al. 2001, Kawa and Oyuela-Caycedo 2008). Our study identified cases, e.g., swiddens used for watermelon cultivation, in which market demand led to overintensification because it resulted in ADE degradation (see also Junqueira et al. 2016). To date, farmers and researchers have assumed that degradation of $\mathrm{ADE}$, as well as NAS, can be solved with longer fallow periods allowing these soils to regain their fertility and to reduce weed pressure. Hiraoka et al. (2003) reported a case of long-term vegetable farming on ADE south of Santarem, in which ADE fertility is maintained by periodic fallowing. In fact, we also identified many cases in which farmers manage ADE under moderately intensive systems that seem to be relatively sustainable in the long-term. However, with increasing market pressures and stimulus from the extension agency to cultivate ADE with nutrient-demanding crops with strong market demand, cases of overintensification on ADE are likely to occur more often, leading not only to depletion of soil nutrients, but also to increased use of agrochemicals. This indicates that increasing intensification can be a potential threat to $\mathrm{ADE}$ and can undermine the importance of these soils for agricultural production, for the conservation of agrobiodiversity, and for local livelihoods.

We also found that farmer rationales for the use of ADE involves more than soil fertility per se, with its capacity to sustain more intensive cultivation. Labor requirements of soils and crops are a salient feature in farmers' discourses. Opening swiddens and weeding are extremely labor-intensive activities, which explains why labor is such an important element in farmers' decisions about which soils to use and which swiddens to open. Farmers acknowledge changes in their social environment (Fig. 3), driven mainly by increased transportation, communication, and education opportunities, resulting in out-migration, greater market integration, and the presence of extension organizations.
Some of these changes limit labor availability and/or increase the costs of labor. It is likely, therefore, that farmers will simultaneously maintain extensive long-fallow swiddens on soils with lower fertility, because of their lower labor demand, and smaller, more intensive short-fallow swiddens on ADE (Junqueira et al. 2016). This multifunctionality can be an effective strategy to cope with risk, particularly suited to the fragile market structures, insecure land tenure, and restricted access to credit that characterize most of rural Amazonia (van Vliet et al. 2012), and therefore should be further explored by extension agents and/or initiatives supporting farmers in developing their production and livelihood options.

\section{CONCLUSIONS}

Future developments are difficult to predict in the dynamic context of rural Amazonia. Drawing from local knowledge and rationales, we showed how farmers whose livelihoods depend strongly on agricultural production interact with the heterogeneity and the dynamics of their agro-ecological and socioeconomic context, adapting their farming strategies accordingly (Fig. 3). They are likely to make well-informed decisions, given their integrated knowledge and understanding of the dynamic interactions of soils and vegetation. The observation that overintensification can lead to ADE degradation suggests the need to research the role of fallows in ADE resilience, as well as nutrient depletion and other biophysical and social consequences of intensified ADE production systems. Our results also indicate that attempting to enhance productivity of ADE and of other soils while disregarding other biophysical and social components of the system may lead to biased support for farmers who practice shifting cultivation in Amazonia. Exploring options to optimize the production of diverse and diversified systems, involving ADE as well as NAS, also requires attention. Finally, based on these findings, we argue that to develop sustainable pathways for the future of smallholder agriculture on ADE and on NAS, it is crucial to understand farmers' knowledge and rationales and integrate them into the research, development, and extension network.

Responses to this article can be read online at: http://www.ecologyandsociety.org/issues/responses. $\mathrm{php} / 8140$

\section{Acknowledgments:}

We thank the local residents of the villages along the middle and lower Madeira River for their invaluable help, support, and friendliness, without which this research would not have been possible. We also thank the Institute for Sustainable Agriculture and Forestry Development of Amazonas State (Instituto de Desenvolvimento Agropecuário e Florestal Sustentável do Estado do Amazonas), the Chico Mendes Institute for Biodiversity Conservation (Instituto Chico Mendes para a Conservação da Biodiversidade) and the Brazilian International Institute of Education (Instituto Internacional de Educação do Brasil) for logistical support. This research was authorized by the Brazilian National Research Ethics Commission (Comissão Nacional de Ética em Pesquisa, CAAE\#011488712.3.0000.0006, Auth. 
\#231.032). Research authorization for villages inside conservation units (Água Azul - Rio Amapá Sustainable Development Reserve, and São Félix do Aripuanã - Juma Sustainable Development Reserve) was obtained from the Amazonas State Centre for Conservation Units (Centro Estadual de Unidades de Conservação, Proc.\#1017/2012). ABJ received PhD. scholarships and research funding from the Terra Preta Program, funded by the Interdisciplinary Research and Education Fund (INREF) of Wageningen University, and from the Netherlands Organisation for International Cooperation in Higher Education (NUFFIC). We thank Simon Jeffery and two anonymous reviewers for improving an earlier version of this manuscript.

\section{LITERATURE CITED}

Adams, C., R. S. S. Murrieta, W. A. Neves, and M. Harris, editors. 2009. Amazon peasant societies in a changing environment: political ecology, invisibility and modernity in the rainforest. Springer, New York, New York, USA. http://dx.doi.org/10.1007/978-1-4020-9283-1

Almekinders, C. J. M., L. O. Fresco, and P. C. Struik. 1995. The need to study and manage variation in agro-ecosystems. Netherlands Journal of Agricultural Science 43:127-142. [online] URL: http://library.wur.n1/ojs/index.php/njas/article/view/572

Boserup, E. 1965. The conditions of agricultural growth: the economics of agrarian change under population pressure. George Allen and Unwin, London, UK.

Chauvel, A., Y. Lucas, and R. Boulet. 1987. On the genesis of the soil mantle of the region of Manaus, Central Amazonia, Brazil. Experimentia 43:234-241. http://dx.doi.org/10.1007/BF01945546

Clarke, W. C. 1976. Maintenance of agriculture and human habitats within the tropical forest ecosystem. Human Ecology 4 (3):247-259. http://dx.doi.org/10.1007/bf01534289

Coomes, O. T., F. Grimard, and G. J. Burt. 2000. Tropical forests and shifting cultivation: secondary forest fallow dynamics among traditional farmers of the Peruvian Amazon. Ecological Economics 32:109-124. http://dx.doi.org/10.1016/S0921-8009(99) $\underline{00066-X}$

Cramb, R. A. 2005. Farmers'strategies for managing acid upland soils in Southeast Asia: an evolutionary perspective. Agriculture, Ecosystems and Environment 106(1):69-87. http://dx.doi. org/10.1016/j.agee.2004.07.011

Cramb, R. A., C. J. P. Colfer, W. Dressler, P. Laungaramsri, Q. T. Le, E. Mulyoutami, N. L. Peluso, and R. L. Wadley. 2009. Swidden transformations and rural livelihoods in Southeast Asia. Human Ecology 37(3):323-346. http://dx.doi.org/10.1007/s10745-009-9241-6

Ellis, F. 1998. Household strategies and rural livelihood diversification. Journal of Development Studies 35(1):1-38. http:// dx.doi.org/10.1080/00220389808422553

Evenson, R. E., and D. Gollin. 2003. Assessing the impact of the Green Revolution, 1960 to 2000. Science 300(5620):758-762. http://dx.doi.org/10.1126/science. 1078710

Feintrenie, L., S. Schwarze, and P. Levang. 2010. Are local people conservationists? Analysis of transition dynamics from agroforests to monoculture plantations in Indonesia. Ecology and Society 15(4):37. [online] URL: http://www.ecologyandsociety. org/vol15/iss4/art37/
Fraser, J. A. 2010b. Caboclo horticulture and Amazonian dark earths along the middle Madeira River, Brazil. Human Ecology 38(5):651-662. http://dx.doi.org/10.1007/s10745-010-9338-y

Fraser, J. A. 2010a. The diversity of bitter manioc (Manihot esculenta Crantz) cultivation in a whitewater Amazonian landscape. Diversity 2(4):586-609. http://dx.doi.org/10.3390/ $\underline{\mathrm{d} 2040586}$

Fraser, J. A., A. Alves-Pereira, A. B. Junqueira, N. Peroni, and C. R. Clement. 2012. Convergent adaptations: bitter manioc cultivation systems in fertile anthropogenic dark earths and floodplain soils in Central Amazonia. PLoS ONE 7(8):e43636. http://dx.doi.org/10.1371/journal.pone.0043636

Fraser, J. A., and C. R. Clement. 2008. Dark earths and manioc cultivation in Central Amazonia: a window on pre-Columbian agricultural systems? Boletim do Museu Paraense Emilio Goeldi, Ciências Humanas 3(2):175-194. http://dx.doi.org/10.1590/ $\underline{\mathrm{S} 1981-81222008000200004}$

Fraser, J., A. B. Junqueira, and C. R. Clement. $2011 a$. Homegardens on Amazonian dark earths, non-anthropogenic upland, and floodplain soils along the Brazilian middle Madeira river exhibit diverging agrobiodiversity. Economic Botany 65 (1):1-12. http://dx.doi.org/10.1007/s12231-010-9143-y

Fraser, J., A. B. Junqueira, N. C. Kawa, C. P. Moraes, and C. R. Clement. 2011b. Crop diversity on anthropogenic dark earths in Central Amazonia. Human Ecology 39(4):395-406. http://dx.doi. org/10.1007/s10745-011-9405-Z

German, L. 2003b. Ethnoscientific understandings of Amazonian dark earths. Pages 179-201 in J. Lehmann, D. C. Kern, B. Glaser, and W. I. Woods, editors. Amazonian dark earths: origin, properties, management. Kluwer Academics, Dordrecht, The Netherlands.

German, L. A. 2003a. Historical contingencies in the coevolution of environment and livelihood: contributions to the debate on Amazonian black earth. Geoderma 111:307-331. http://dx.doi. org/10.1016/S0016-7061(02)00270-7

Glaser, B. 2007. Prehistorically modified soils of Central Amazonia: a model for sustainable agriculture in the twenty-first century. Philosophical Transactions of the Royal Society: Biological Sciences 362:187-196. http://dx.doi.org/10.1098/ rstb.2006.1978

Glaser, B., L. Haumaier, G. Guggenberger, and W. Zech. 2001. The 'Terra Preta' phenomenon: a model for sustainable agriculture in the humid tropics. Naturwissenschaften 88:37-41. http://dx.doi.org/10.1007/s001140000193

Godfray, H. C. J., J. R. Beddington, I. R. Crute, L. Haddad, D. Lawrence, J. F. Muir, J. Pretty, S. Robinson, S. M. Thomas, and C. Toulmin. 2010. Food security: the challenge of feeding 9 billion people. Science 327(5967):812-818. http://dx.doi.org/10.1126/ science. 1185383

Gray, C. L., R. E. Bilsborrow, J. L. Bremner, and F. Lu. 2008. Indigenous land use in the Ecuadorian Amazon: a cross-cultural and multilevel analysis. Human Ecology 36(1):97-109. http://dx. doi.org/10.1007/s10745-007-9141-6 
Hiraoka, M., S. Yamamoto, E. Matsumoto, S. Nakamura, I. C. Falesi, A. Ronaldo, and C. Baena. 2003. Contemporary use and management of Amazonian dark earths. Pages 387-406 in J. Lehmann, D. C. Kern, B. Glaser, and W. I. Woods, editors. Amazonian dark earths: origin, properties, management. Kluwer Academic, Dordrecht, The Netherlands. http://dx.doi. org/10.1007/1-4020-2597-1 20

Junk, W. J., and M. T. F. Piedade. 2010. An introduction to South American wetland forests: distribution, definitions and general characterization. Pages 3-26 in W. J. Junk, M. T. F. Piedade, F. Wittmann, J. Schöngart, and P. Parolin, editors. Amazonian floodplain forests: ecophysiology, biodiversity and sustainable management. Springer, Dordrecht, The Netherlands. http://dx. doi.org/10.1007/978-90-481-8725-6 1

Junqueira, A. B., G. H. Shepard, Jr., and C. R. Clement. 2010. Secondary forests on anthropogenic soils in Brazilian Amazonia conserve agrobiodiversity. Biodiversity and Conservation 19 (7):1933-1961. http://dx.doi.org/10.1007/s10531-010-9813-1

Junqueira, A. B., G. H. Shepard, Jr., and C. R. Clement. 2011. Secondary forests on anthropogenic soils of the middle Madeira river: valuation, local knowledge, and landscape domestication in Brazilian Amazonia. Economic Botany 65(1):85-99. http://dx. doi.org/10.1007/s12231-010-9138-8

Junqueira, A. B., T. J. Stomph, C. R. Clement, and P. C. Struik. 2016. Variation in soil fertility influences cycle dynamics and crop diversity in shifting cultivation systems. Agriculture, Ecosystems and Environment 215:122-132. http://dx.doi.org/10.1016/j. agee.2015.09.015

Kawa, N. C., and A. Oyuela-Caycedo. 2008. Amazonian dark earth: a model of sustainable agriculture of the past and future? International Journal of Environmental, Cultural, Economic and Social Sustainability 4(3):9-16. [online] URL: http://www. academia.edu/900122/Amazonian_Dark_Earth_A_Model_of_Sustainable Agriculture of the Past and Future

Kawa, N. C., D. Rodrigues, and C. R. Clement. 2011. Useful species richness, proportion of exotic species, and market orientation on Amazonian dark earths and oxisols. Economic Botany 65(2):169-177. http://dx.doi.org/10.1007/s12231-011-9158$\underline{\mathrm{Z}}$

Lambin, E. F., B. L. Turner, H. J. Geist, S. B. Agbola, A. Angelsen, J. W. Bruce, O. T. Coomes, R. Dirzo, G. Fischer, C. Folke, P. S. George, K. Homewood, J. Imbernon, R. Leemans, X. Li, E. F. Moran, M. Mortimore, P. S. Ramakrishnan, J. F. Richards, H. Skånes, W. Steffen, G. D. Stone, U. Svedin, T. A. Veldkamp, C. Vogel, and J. Xu. 2001. The causes of land-use and land-cover change: moving beyond the myths. Global Environmental Change 11(4):261-269. http://dx.doi.org/10.1016/s0959-3780(01)00007-3

Laurance, W. F., M. A. Cochrane, S. Bergen, P. M. Fearnside, P. Delamônica, C. Barber, S. D'Angelo, and T. Fernandes. 2001. The future of the Brazilian Amazon. Science 291(5503):438-439. http://dx.doi.org/10.1126/science.291.5503.438

Major, J., A. diTommaso, L. A. German, and J. M. McCann. 2003. Weed population dynamics and management on amazonian dark earth. Pages 433-454 in J. Lehmann, D. C. Kern, B. Glaser, and W. I. Woods, editors. Amazonian dark earths: origin, properties, management. Kluwer Academics, Dordrecht, The Netherlands. http://dx.doi.org/10.1007/1-4020-2597-1_22

Major, J., A. Ditommaso, J. Lehmann, and N. P. S. Falcão. 2005. Weed dynamics on Amazonian dark earth and adjacent soils of Brazil. Agriculture, Ecosystems and Environment 111(1-4):1-12. http://dx.doi.org/10.1016/j.agee.2005.04.019

Marquardt, K., R. Milestad, and R. Porro. 2013. Farmers' perspectives on vital soil-related ecosystem services in intensive swidden farming systems in the Peruvian Amazon. Human Ecology 41(1):139-151. http://dx.doi.org/10.1007/s10745-012-9522-3

McCusker, B., and E. R. Carr. 2006. The co-production of livelihoods and land use change: case studies from South Africa and Ghana. Geoforum 37(5):790-804. http://dx.doi.org/10.1016/ j.geoforum.2005.09.007

Mertz, O. 2002. The relationship between length of fallow and crop yields in shifting cultivation: a rethinking. Agroforestry Systems 55(2):149-159. http://dx.doi.org/10.1023/A:1020507631848

Mertz, O., R. L. Wadley, U. Nielsen, T. B. Bruun, C. J. P. Colfer, A. de Neergaard, M. R. Jepsen, T. Martinussen, Q. Zhao, G. T. Noweg, and J. Magid. 2008. A fresh look at shifting cultivation: fallow length an uncertain indicator of productivity. Agricultural Systems 96(1-3):75-84. http://dx.doi.org/10.1016/j.agsy.2007.06.002

Mittermeier, R. A., C. G. Mittermeier, T. M. Brooks, J. D. Pilgrim, W. R. Konstant, G. A. B. da Fonseca, and C. Kormos. 2003. Wilderness and biodiversity conservation. Proceedings of the National Academy of Sciences 100(18):10309-10313. http://dx. doi.org/10.1073/pnas. 1732458100

Moraes, C. P., and E. G. Neves. 2012. O ano 1000: adensamento populational, interação e conflito na Amazônia Central. Amazônica 4(1):122-148. [online] URL: http://periodicos.ufpa.br/ index.php/amazonica/article/viewArticle/884/1270

Neves, E. G., J. B. Petersen, R. N. Bartone, and C. A. da Silva. 2003. Historical and socio-cultural origins of Amazonian dark earths. Pages in J. Lehmann, D. C. Kern, B. Glaser, and W. I. Woods, editors. Amazonian dark earths: origin, properties, management. Kluwer Academics, Dordrecht, The Netherlands. http://dx.doi.org/10.1007/1-4020-2597-1 3

Nielsen, U., O. Mertz, and G. T. Noweg. 2006. The rationality of shifting cultivation systems: labor productivity revisited. Human Ecology 34(2):201-218. http://dx.doi.org/10.1007/s10745-006-9014-4

Nye, P. H., and D. J. Greenland. 1960. The soil under shifting cultivation. Technical communication no. 51. Commonwealth Agricultural Bureau, Harpenden, UK.

Padoch, C., E. Brondizio, S. Costa, M. Pinedo-Vasquez, R. R. Sears, and A. Siqueira. 2008. Urban forest and rural cities: multisited households, consumption patterns, and forest resources in Amazonia. Ecology and Society 13(2):2. [online] URL: http:// www.ecologyandsociety.org/voll3/iss2/art2/

Padoch, C., and M. Pinedo-Vasquez. 2010. Saving slash-and-burn to save biodiversity. Biotropica 42(5):550-552. http://dx.doi. org/10.1111/j.1744-7429.2010.00681.x

Padoch, C., and T. C. H. Sunderland. 2014. Managing landscapes for greater food security and improved livelihoods. Unasylva 64 
(241):3-13. [online] URL: http://www.cifor.org/library/4362/ managing-landscapes-for-greater-food-security-and-improved-livelihoods/

Parry, L., B. Day, S. Amaral, and C. A. Peres. 2010. Drivers of rural exodus from Amazonian headwaters. Population and Environment 32(2):137-176. http://dx.doi.org/10.1007/s11111-010-0127-8

Rudel, T. K., D. Bates, and R. Machinguiashi. 2002. A tropical forest transition? Agricultural change, out-migration, and secondary forests in the Ecuadorian Amazon. Annals of the Association of American Geographers 92(1):87-102. http://dx.doi. org/10.1111/1467-8306.00281

Serrão, E. A. S., D. Nepstad, and R. Walker. 1996. Upland agricultural and forestry development in the Amazon: sustainability, criticality and resilience. Ecological Economics 18 (1):3-13. http://dx.doi.org/10.1016/0921-8009(95)00092-5

Soares-Filho, B. S., D. C. Nepstad, L. M. Curran, G. C. Cerqueira, R. A. Garcia, C. A. Ramos, E. Voll, A. McDonald, P. Lefebvre, and P. Schlesinger. 2006. Modelling conservation in the Amazon basin. Nature 440(7083):520-523. http://dx.doi.org/10.1038/ $\underline{\text { nature } 04389}$

Steward, A. 2007. Nobody farms here anymore: livelihood diversification in the Amazonian community of Carvão, a historical perspective. Agriculture and Human Values 24(1):75-92. http://dx.doi.org/10.1007/s10460-006-9032-2

van Vliet, N., C. Adams, I. C. G. Vieira, and O. Mertz. 2013. "Slash and burn" and "shifting" cultivation systems in forest agriculture frontiers from the Brazilian Amazon. Society and Natural Resources 26(12):1454-1467. http://dx.doi. org/10.1080/08941920.2013.820813

van Vliet, N., O. Mertz, A. Heinimann, T. Langanke, U. Pascual, B. Schmook, C. Adams, D. Schmidt-Vogt, P. Messerli, S. Leisz, J.-C. Castella, L. Jørgensen, T. Birch-Thomsen, C. Hett, T. BechBruun, A. Ickowitz, K. C. Vu, K. Yasuyuki, J. Fox, C. Padoch, W. Dressler, and A. D. Ziegler. 2012. Trends, drivers and impacts of changes in swidden cultivation in tropical forest-agriculture frontiers: a global assessment. Global Environmental Change 22 (2):418-429. http://dx.doi.org/10.1016/j.gloenvcha.2011.10.009

Weinstein, B. 1983. The Amazon rubber boom: 1850-1920. Stanford University Press, Palo Alto, California, USA.

WinklerPrins, A. M. G. A., and S. P. Aldrich. 2010. Locating Amazonian dark earths: creating an interactive GIS of known locations. Journal of Latin American Geography 9(3):33-50. 